\title{
Artigo Original / Original Paper Ambrosiinae e Helianthinae (Heliantheae - Asteraceae) na Amazônia Legal brasileira
}

\author{
The subtribes Ambrosiinae and Helianthinae (Heliantheae - Asteraceae)
}

in the Brazilian Amazon

\author{
Markus Meireles Campos ${ }^{1,3,4}$, Climbiê Ferreira Hall ${ }^{2}$ \& João Ubiratan Moreira dos Santos ${ }^{1}$
}

\begin{abstract}
Resumo
O trabalho apresenta o tratamento taxonômico das espécies das subtribos Ambrosiinae e Helianthinae, pertencentes a tribo Heliantheae (Asteraceae), na Amazônia Legal brasileira. São apresentadas chaves de identificação, descrições, ilustrações detalhadas, comentários e distribuição geográfica das espécies. Foram encontrados três gêneros em Ambrosiinae, totalizando quatro espécies e dois gêneros em Helianthinae, somando sete espécies. Aldama kunthiana e A. grandiflora figuram como novos registros para o estado do Tocantins e A. oblongifolia como nova ocorrência para o Acre. Parthenium hysterophorus foi registrado pela primeira vez no estado do Amazonas.
\end{abstract}

Palavras-chave: Compositae, Região Norte, taxonomia.

\begin{abstract}
The work presents a taxonomic treatment of the subtribes Ambrosiinae and Helianthinae, belonging to the tribe Heliantheae (Asteraceae), in the Brazilian Legal Amazon. We present identification keys, descriptions, detailed illustrations, comments and geographical distribution of the species. Three genera were found in Ambrosiinae, totaling four species and two genera for Helianthinae, adding seven species. Aldama kunthiana and $A$. grandiflora appear as new records for the state of Tocantins and A. oblongifolia as a new occurrence for Acre. Parthenium hysterophorus was first recorded in the state of Amazonas.
\end{abstract}

Key words: Compositae, North Region, taxonomy.

\section{Introdução}

Asteraceae possui distribuição cosmopolita com cerca de 24.000 espécies, o que equivale a aproximadamente $10 \%$ das Angiospermas (Funk et al. 2009). No Brasil, são descritos 280 gêneros e mais de 2.000 espécies (BFG 2018).

Asteraceae possui 12 subfamílias e 43 tribos (Funk et al. 2009; Panero et al. 2014), sendo $70 \%$ das espécies alocadas em Asteroideae, que abrange cerca de 17.000 espécies (Anderberg et al. 2007). Nessa subfamília destaca-se a tribo Heliantheae, que no Brasil inclui ca. 220 espécies alocadas em 32 gêneros (BFG 2018). No Brasil, alguns trabalhos envolvendo Heliantheae foram desenvolvidos, tais como Magenta (1998), Santos (2001), Nakajima \& Semir (2001), Mondin (2007), Bringel Jr. \& Cavalcanti (2009), Silva \& Santos (2010) e Alves \& Roque (2016).

Entre as características morfológicas comuns de Heliantheae estão o hábito herbáceo; a filotaxia geralmente oposta; os capítulos com receptáculos paleáceos e flores geralmente amarelas; as flores do raio com corola do raio verdadeira, podendo ser neutras ou femininas; flores do disco andróginas

\footnotetext{
${ }^{1}$ Universidade Federal Rural da Amazônia / Museu Paraense Emílio Goeldi, Campus pesquisa, Prog. Pós-graduação em Botânica Tropical, Av. Perimetral 1901, Terra Firme, 66077-530, Belém, PA, Brasil.

${ }^{2}$ Universidade Federal do Mato Grosso do Sul, Av. Cap. Olinto Mancini 1662, Colinos, 79600-080, Três Lagoas, MS, Brasil.

${ }^{3}$ ORCID: < https://orcid.org/0000-0002-1390-2754>

${ }^{4}$ Autor para correspondência: markus_mmc@yahoo.com.br
} 
ou funcionalmente masculinas, com anteras negras (Robinson 1981; Santos 2001; Funk et al. 2009). Panero (2007), a partir de estudos morfológicos e filogenéticos, considera a existência de 15 subtribos em Heliantheae, entre elas Ambrosiinae e Helianthinae.

Ambrosiinae apresenta oito gêneros (Panero 2007), mas somente Ambrosia L., Parthenium L. e Xanthium L., são citados para a Amazônia Legal (BFG 2018, Fig. 1). Ambrosiinae são ervas anuais ou perenes, raramente arbóreas; com polinização anemofílica; folhas alternas, simples; capítulos unissexuados, com invólucro campanulado; anteras com apêndices glabros; e cipselas não estriadas (Robinson 1981; Panero 2007).

Helianthinae possui 19 gêneros (Panero 2007), sendo que para a Amazônia Legal brasileira foi relatada a ocorrência dos gêneros Aldama La Llave. e Tithonia Desf. ex Juss. (BFG 2018, Fig. 2). Helianthinae possui filotaxia alterna; capítulos terminais ou raramente axilares, com duas séries de brácteas involucrais; pálea persistente, raramente decídua; flores do disco bissexuadas com corolas pentâmeras; flores do raio neutras; pápus presente, com duas aristas; cipselas do raio filiformes; resina de cor amarela (Robinson 1981; Panero 2007).

Heliantheae possui cinco subtribos no cenário amazônico (Ambrosiinae, Ecliptinae, Helianthinae, Spilanthinae e Zinninae). No entanto, as contribuições taxonômicas voltadas com exclusividade para essa área restringem-se a Silva \& Santos (2010) com a subtribo Ecliptinae, ficando, portanto, evidenciada a necessidade de mais estudos. Assim, neste trabalho apresentamos o tratamento taxonômico das espécies das subtribos Ambrosiinae e Helianthinae (Heliantheae Asteraceae) na Amazônia Legal brasileira.

\section{Material e Métodos}

A área de estudo corresponde à Amazônia Legal brasileira, sendo esta uma delimitação política brasileira que inclui os estados do Roraima, Amazonas, Acre, Rondônia, Amapá, Pará, Tocantins, Mato Grosso e parte oeste do Maranhão (IBGE 2017). Encontra-se dividida em áreas florestais, subdivididas em matas de terra firme, várzea, igapó e regiões litorâneas (mangues); e áreas não florestais, que compreendem os campos de terra firme, campinas, restingas litorâneas e campos de várzea, além de manchas de vegetação serrana baixa e um cerrado mais predominante em direção ao Centro-Oeste (Ter Steege et al. 2003).

Foram analisadas exsicatas das espécies de interesse nos seguintes herbários: MG, IAN, INPA, RB, R e de herbários virtuais que possuíam fotos disponíveis tais como: NY, CEN, UB, MO, RON, ALCB, EAC, HUEFS e FURB (acrônimos segundo Thiers, continuamente atualizado). Para a padronização das descrições foi feita uma planilha contendo cerca de 100 caracteres. Comentários sobre o hábitat, distribuição geográfica, nomes populares e outras informações pertinentes, foram retirados das etiquetas do material e da literatura especializada referente às espécies. O material herborizado foi descrito e ilustrado com o auxílio de um microscópio estereoscópico. Para a observação de detalhes das estruturas reprodutivas, os capítulos florais foram colocados em água fervente para hidratação sempre que necessário. Os conceitos de Radford et al. (1974), Gonçalves \& Lorenzi (2011), Vidal \& Vidal (2006), Roque \& Bautista (2008) foram utilizados para a interpretação das estruturas morfológicas.

\section{Resultados e Discussão}

\section{Chave de identificação das subtribos de Heliantheae na Amazônia Legal Brasileira}

1. Capítulos unissexuais Ambrosiinae

1'. Capítulos bissexuais. 2

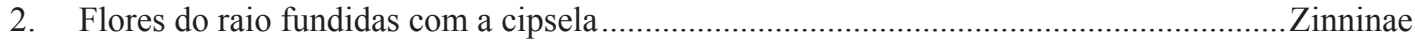

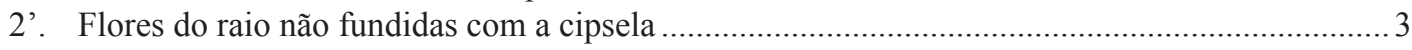

3. Cipselas estriadas Helianthinae

3'. Cipselas não estriadas Spilanthinae

4. Margem da cipsela ciliada ..Ecliptinae

4'. Margem da cipsela não ciliada 4 


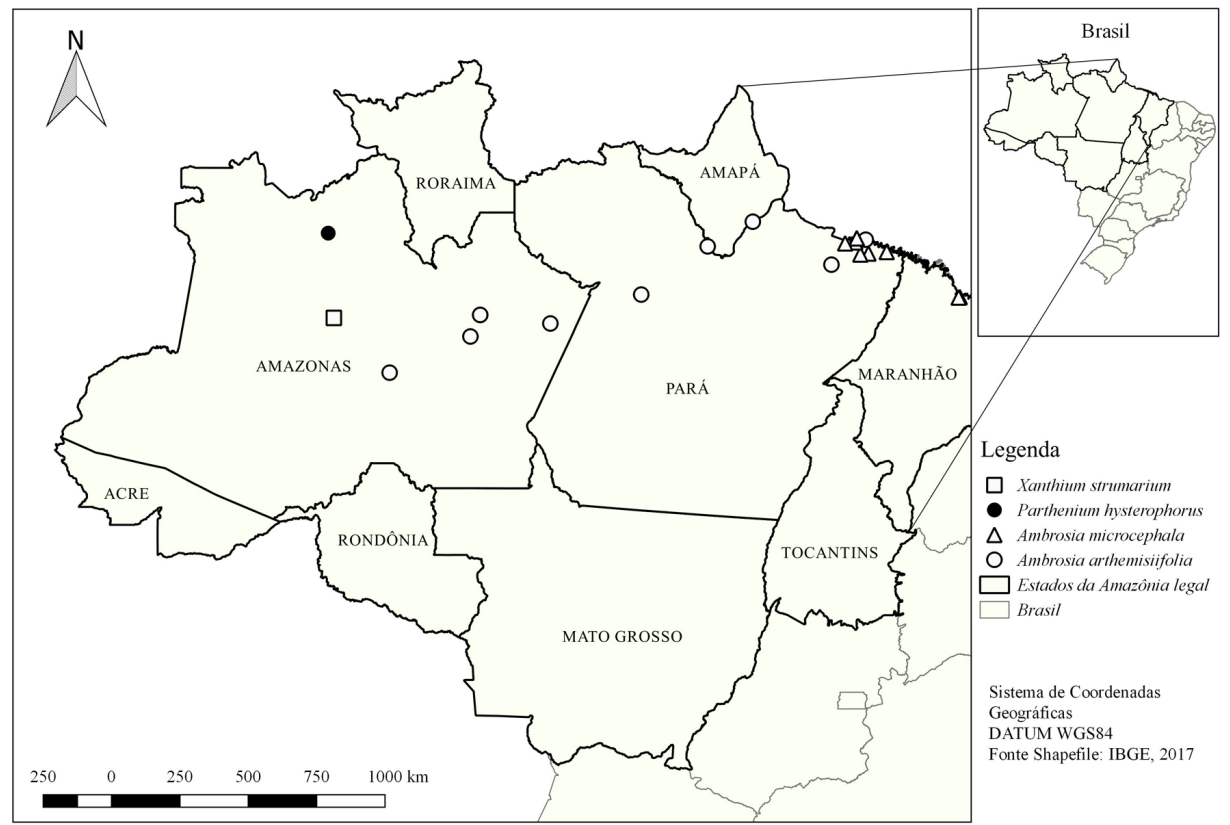

Figura 1 - Distribuição das espécies dos gêneros Ambrosia, Parthenium e Xanthium da subtribo Ambrosiinae na Amazônia Legal brasileira.

Figure 1 - Distribution of species of the genera Ambrosia, Parthenium and Xanthium of the Ambrosinae subtribe in the Brazilian Legal Amazon.

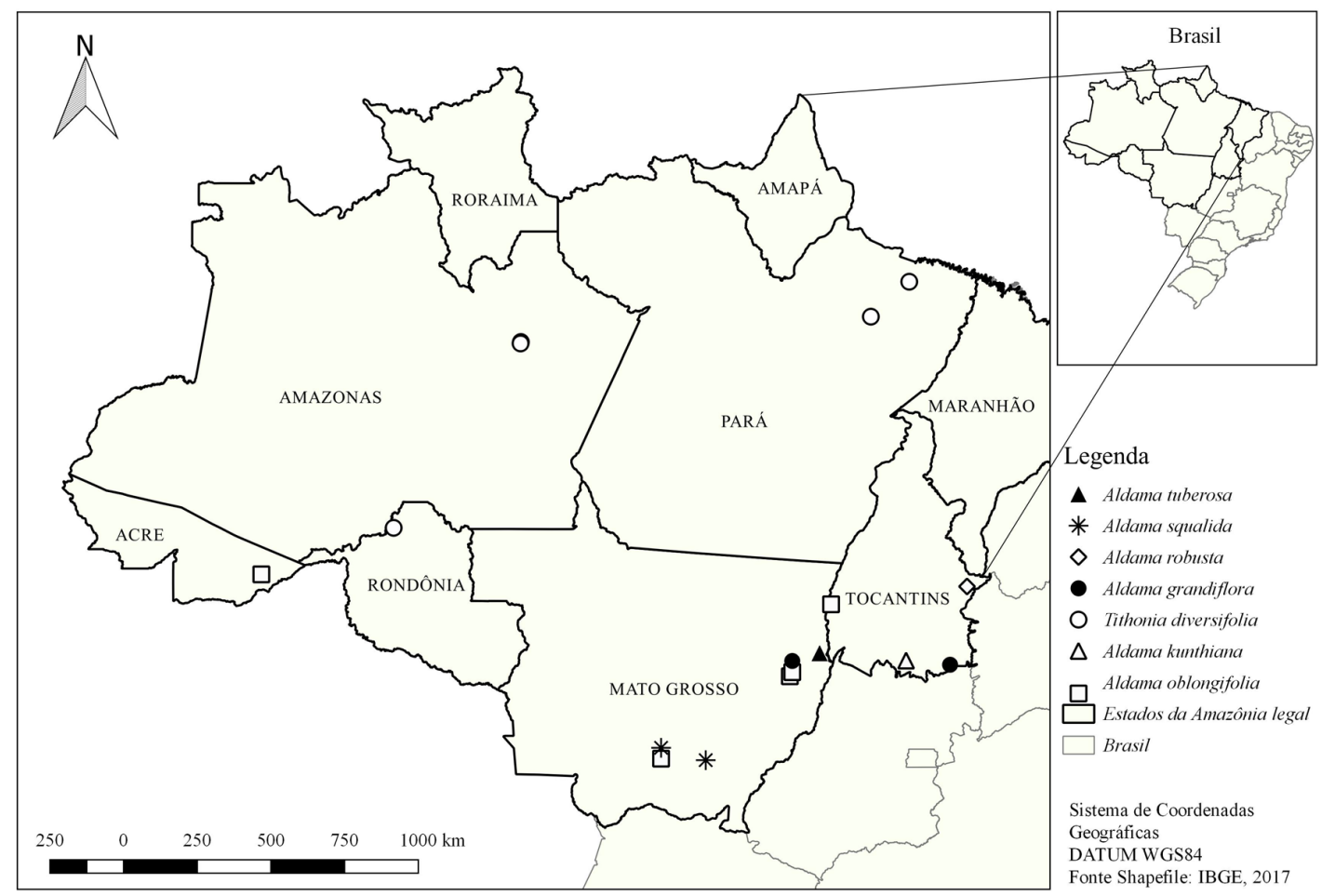

Figura 2 - Distribuição das espécies dos gêneros Tithonia e Aldama da subtribo Helianthinae na Amazônia Legal brasileira.

Figure 2 - Distribution of species of the genera Tithonia and Aldama of the Helianthinae subtribe in the Brazilian Legal Amazon. 
Chave de identificação dos gêneros da subtribo Ambrosiinae na Amazônia Legal brasileira

1. Capítulos bissexuados 2. Parthenium

1'. Capítulos unissexuados

2. Capítulo masculino com brácteas involucrais livres; Capítulo feminino com duas flores

3. Xanthium

2'. Capítulo masculino com brácteas involucrais fundidas; capítulo femininos com uma flor.

1. Ambrosia

\section{Ambrosia L.}

Ervas ou subarbustos. Folhas alternas, lâmina pinatipartida ou pinatífida. Capítulos discoides, unissexuados; os femininos na base de uma capitulescência espiciforme, brácteas involucrais completamente fundidas, apresentando projeções agudas, raro ausentes, unifloros sem perianto; os masculinos no ápice da capitulescência, brácteas parcialmente concrescidas, invólucro campanulado; receptáculo paleáceo com páleas filiformes. Flores femininas nuas; as funcionalmente masculinas com corolas tubulosas ou infundibuliformes; lacínias
5, anteras 5, com apêndice do conectivo deltoide. Cipselas obovoides, glabras; pápus ausente.

O gênero Ambrosia apresenta 51 espécies com distribuição tropical, sobretudo na América Central e América do Sul, das quais seis ocorrem no Brasil (BFG 2018; Davidse et al. 2018; The Plant List 2013; Alves 2018a). Seus capítulos unissexuados, os femininos geralmente sendo unifloros, identificam facilmente o grupo. Ocorre em área Antrópica, Cerrado, Floresta de Terra Firme, Floresta Ombrófila, Floresta Ombrófila Mista e Restinga (Alves 2018a).

\section{Chave de identificação das espécies de Ambrosia na Amazonia Legal Brasileira}

1. Invólucro feminino não costado, com projeções conspicuamente espiciformes; folhas pinatipartidas; venação craspedódroma. 1.1. Ambrosia artemisiifolia

1'. Invólucro feminino ligeiramente costado, com projeções triangulares; folhas pinatífidas; venação broquidódroma 1.2. Ambrosia microcephala

1.1. Ambrosia artemisiifolia L., Species Plantarum 2: 988.1753.

Fig. 3a-f

Erva ou subarbusto $0,5-2 \mathrm{~m}$ alt.; ramos eretos, sublenhosos, pilosos, cilíndricos, entrenós 1-5 cm compr. Folhas discolores, pecíolos $0,8-4$ cm compr., lâmina foliar 4-14 × 1,5-9,5 cm, pinatipartida, pilosa em ambas as faces, base atenuada, ápice agudo, margem inteira, nervação craspedródoma. Capítulos masculinos 1-2 × 2-4 $\mathrm{mm}$, receptáculo plano ou convexo, ca. $0,2-0,5$ $\times 0,5 \mathrm{~mm}$; brácteas involucrais unisseriadas, ca. 1,5 mm compr., ápice deltoide, foliáceas, esparsamente pilosas externamente, glabras internamente; páleas ca. 1,5 ×0,1 mm, nervura principal 1, membranáceas; capítulos femininos ca. $2 \times 3 \mathrm{~mm}$, invólucro gamofilo globoso, envolvendo totalmente a cipsela, com projeções conspicuamente espiciformes. Flores masculinas ca. 20, corola ca. $2 \times 1 \mathrm{~mm}$, infundibuliforme, lacínias deltoides, voltadas para dentro do tubo, creme, anteras ca. $1 \mathrm{~mm}$ compr., castanhas, apêndice do conectivo deltoide, base curto sagitada, filete ca. $0,3 \mathrm{~mm}$ compr.; flor feminina com ovário ca. $2 \mathrm{~mm}$ compr., obovado, glabro, estilete ca. 1,2 mm compr., ramos estigmáticos ca. $1 \mathrm{~mm}$ compr., amarelo, truncado. Cipsela ca. 3-3,5 $\times 2 \mathrm{~mm}$, enegrecida.

Material examinado: AMAPÁ: Macapá, praia do Araxá, 18.XI.1979, fl. e fr., D.F Austin et al. 7429 (MG). AMAZONAS: Careiro, campo de gado, 19.IV.1973, fl. e fr., J. Coelho (MG 50404); Manaus, margens do igarapé do parque 10, 17.XII.1954, fl. e fr., Chagas (MG 23059); pântano da beira, II.1901, fl. e fr., Ule 5707 (MG); porto CEASA, 26.II.2004, fl. e fr., Hyelen (INPA 214916). Maués, Rio Solimões, 1.II.1975, fl. e fr., W. Junk 273 (INPA). PARÁ: Almerin, Rio Maicurú, campo de várzea, 20.XII.1956, fl. e fr., J.M. pires et al. 6547 (IAN). Santarém, várzea do Arapari, 29.I.1979, fl. e fr., L.O.A Teixeira 16 (MG); Cacaual grande, 27.X.1950, fl. e fr., G.A. Black \& P. Ledoux 50 (IAN).

Material adicional examinado: BRASIL. DISTRITO FEDERAL: Recreio dos Bandeirantes, 22.X.1936, fl. e fr., Alston 168 (R). MINAS GERAIS: Belo Horizonte, bairro Serra, 17.IV.1965, fl. e fr., L. Roth (RB 93107). 


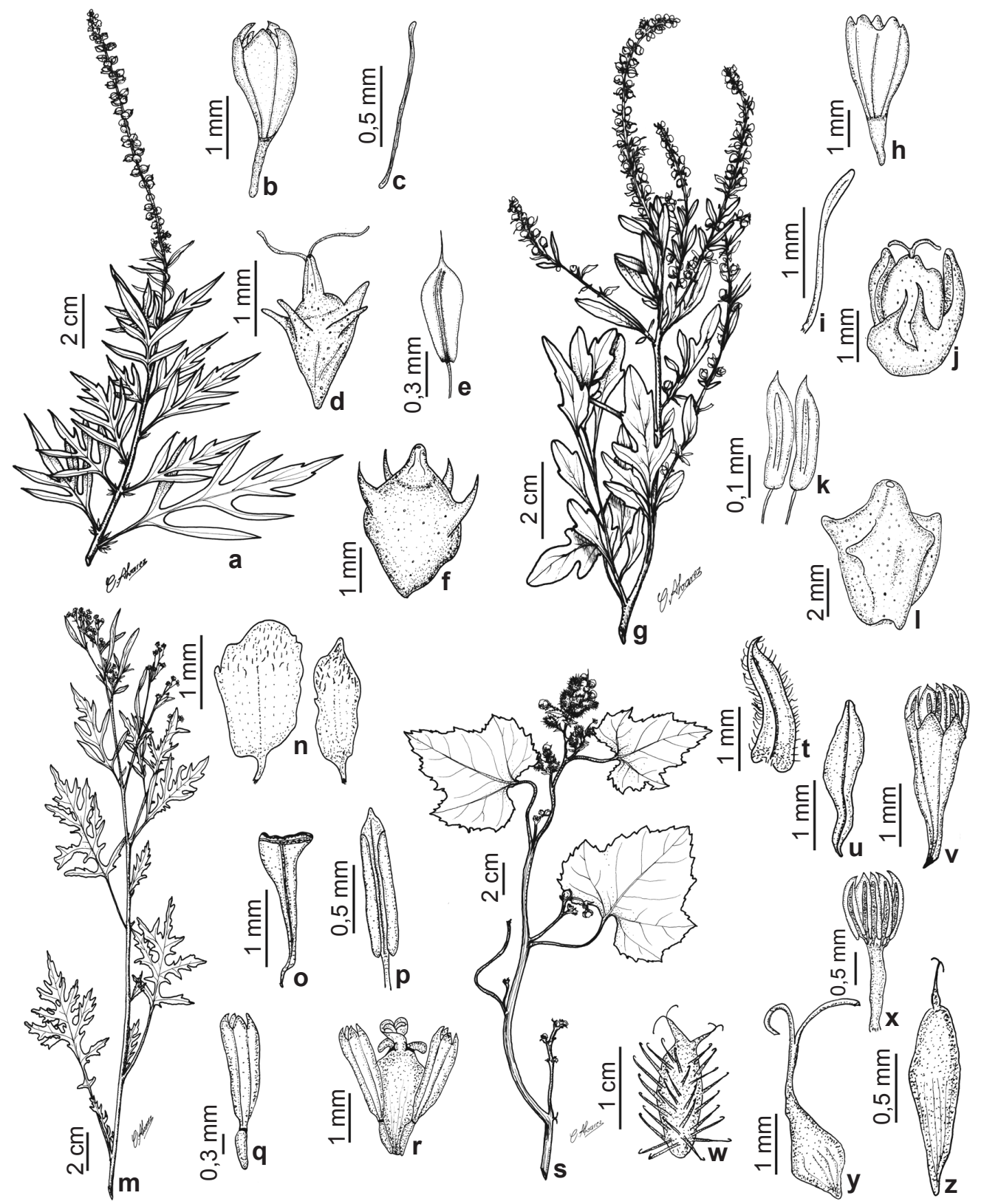

Figura 3 - a-f. Ambrosia artemisiifolia - a. hábito; b. flor masculina; c. pálea; d. capítulo feminino imaturo com brácteas involucrais totalmente fundidas; e. antera; f. capítulo feminino com cipsela madura. g-1. Ambrosia microcephala - g. hábito; h. flor masculina; i. pálea; j. capítulo feminino imaturo com brácteas totalmente fundidas e presença de bractéolas; k. antera; 1 . capítulo feminino com cipsela madura. m-r. Parthenium hysterophorus - m. hábito; n. bráctea involucral externa (esquerda) e bráctea involucral interna (direita); o. pálea; p. antera; q. flor masculina; r. cipsela associada a duas flores do disco. s-z. Xanthium strumarium - s. hábito; t. bráctea involucral; u. pálea; v. flor masculina; w. capítulo feminino bifloro; x. anteras; y. flor feminina nua; z. cipsela. (a-f. W. Junk 273; g-1. A.S. Mesquita 100; m-r. O.S. Ribas \& J. Cordeiro 469; s-z. F.F.S. Silva 602). (Ilustração: a,g,m,s. Carlos Alvarez; b-f,h-l,n-r,t-z. Markus Campos).

Figure 3 - a-f. Ambrosia artemisiifolia - a. habit; b. male floret; c. palea; d. female head immature with involucral bracts totally fused; e. anther; f. female head with mature cypsela. g-1. Ambrosia microcephala - g. habit; h.male floret; i. palea; j. female head immature with involucral bracts totally fused and presence of bractolas; $\mathrm{k}$. anther; 1 . female head with mature cypsela. m-r. Parthenium hysterophorus - $\mathrm{m}$. habit; $\mathrm{n}$. involucral bract external (left) and involucral bract internal (right); o. palea; p. anther; q. male floret; r. cypsela associate two disc florets. s-z. Xanthium strumarium -s. habit; t. involucral bract; u. palea; v. male floret; w. female head with two florets; x. anthers; y. female floret naked; z.cypsela. (a-f. W. Junk 273; g-l. A.S. Mesquita 100; m-r. O.S. Ribas \& J. Cordeiro 469; s-z.F.F.S. Silva 602). (Illustration: a,g,m,s. Carlos Alvarez; b-f,h-l,n-r,t-z. Markus Campos). 
SÃO PAULO: São Paulo, Alto da Lapa, 18.X.1943, fl. e fr., W. Hoehne (RB 325211).

Nome popular: "Artemisia"

A planta é próxima de $A$. microcephala, mas diferencia-se desta facilmente pelas suas folhas pinatipartidas e invólucro com projeções pontiagudas ( $v s$. folhas pinatífidas e projeções triangulares). Jorgensen \& Nee (2014) relata registros da espécie no Equador, Chile, Bolívia e Brasil. Pode ser encontrada nos estados do Acre, Amazonas, Amapá, Pará, Rondônia, Bahia, Ceará, Paraíba, Mato Grosso do Sul, Minas Gerais, Rio de Janeiro, São Paulo, Paraná, Rio Grande do Sul e Santa Catarina (Alves 2018a). Ocorre em campos de várzea, beiras de rio, campo de gado, dunas e praias. Floresce e frutifica o ano inteiro.

1.2. Ambrosia microcephala DC., Prodomus Systematis Naturalis Regni Vegetabilis 5: 527.1836.

Fig. 3g-1

Erva ou subarbusto, $20-50 \mathrm{~cm}$ alt.; ramos eretos, glabros, entrenós $1-3,5 \mathrm{~cm}$. Folhas concolores, pecioladas, $1-2 \mathrm{~cm}$ compr., lâmina foliar $0,5-7 \times 0,5-3 \mathrm{~cm}$, pinatipartida, glabra em ambas as faces, base atenuada, ápice atenuado ou cuspidado, margem inteira, nervação broquidódroma, nervuras principais 3. Capítulos masculinos ca. $2-3 \times 2 \mathrm{~mm}$, receptáculo plano ou convexo, ca. $0,3 \times 0,4 \mathrm{~mm}$; páleas ca. $2 \times 0,1 \mathrm{~mm}$, membranáceas; brácteas involucrais em uma série, ca. $3 \mathrm{~mm}$ compr., oblanceoladas a elípticas, base atenuada, fundidas até próximo ao ápice, membranáceas, face externa pilosa e face interna glabra; capítulos femininos ca. $3 \times 2 \mathrm{~mm}$, invólucro gamofilo globoso encobrindo totalmente a cipsela, levemente costado com projeções triangulares; ca. $0,2 \times 0,4 \mathrm{~mm}$ larg.; Flores masculinas 15-20, corola ca. $3 \times 0,5 \mathrm{~mm}$, tubulosa a infundibuliforme, lacínias deltoides, creme ou hialina, antera ca. $0,3 \mathrm{~mm}$ compr., apêndice do conectivo deltóide, base curto sagitada, filete ca. $0,5 \mathrm{~mm}$ compr.; flor feminina com ovário ca. $2 \mathrm{~mm}$ compr., parede glabra, obovoide. Cipsela ca. 3,5-4 × $2 \mathrm{~mm}$, enegrecida.

Material examinado: MARANHÃO: XI.1944, Gardner 6056 (R). São Luis, praia do Araçagi, 28.III.1988, fl. e fr., A. Fernandes 48 (SLUI). PARÁ: Augusto Correia, APA de Urumajo, 19.X.2001, fl. e fr., W.O. Rosa Jr. et al. 37 (MG). Bragança, Lobo grande, 23.III.1979, fl. e fr., B.C. Santiago (MG 62224). Maracanã, ilha de AlgodoalMaiandeua, III.1991, fl. e fr., S. Almeida et al. 443 (MG). Marapanim, praia de Crispim, 23.II.1986, fl. e fr., L.C.B. Lobato et al. 202 (MG); 9.X.1990, fl. e fr., M.N.C. Bastos et al. 590 (MG); 10.XII.1992, fl. e fr., M.N.C. Bastos et al. 1089 (MG); 8.V.1993, fl. e fr., M.N.C. Bastos et al. 1356 (MG); vila de Marudá, 18.XI.1992, fl. e fr., M.N.C. Bastos et al. 1243 (MG); Restinga do Crispim, 11.IV.1997, fl. e fr., S.V.C. Neto 26 (MG). Salvaterra, praia Joanes, 22.I.1979, fl. e fr., N.T. Silva \& C.S. Rosário 4928 (MG). São Caetano de Odivelas, praia Sememboca, 23.II.1971, fl. e fr., Rito 4 (MG).

Material adicional examinado: BRASIL. PIAUÍ: Luiz Correa, praia do Coqueiro, 2.X.1973, fl. e fr., D. Araujo et al. 419 (R).

Nome popular: "Losna"

Funk et al. (2007) citam a distribuição da planta na Guiana Francesa, Suriname e Brasil. Ocorre nos estados do Pará, Bahia, Maranhão, Paraíba e Pernambuco (Alves 2018a). Ocorre em dunas, praias, campos arenosos e áreas de restinga. A espécie encontra-se com flores e frutos o ano inteiro.

\section{Parthenium L.}

Subarbusto; ramos eretos, sublenhosos, cilíndricos, sulcados. Folhas pinatipartidas, alternas. Capitulescência em cimeiras paniculiformes, capítulos radiados, invólucro campanulado. Brácteas involucrais em 2 séries, dimórficas. Receptáculo paleáceo; páleas obdeltóides. Flores do raio femininas 5, alvas, ápice bilobado; as do disco funcionalmente masculinas, corola infundibuliforme, 4 lácinias, deltoides, alva. Anteras 4. Cipselas obovoides; pápus ausente.

O gênero Parthenium possui 15 espécies, distribuindo-se principalmente na América Central e América do Sul (Davidse et al. 2018; The Plant List 2013). No Brasil temos a ocorrência de duas espécies (Alves 2018b). A presença de 5 flores do raio, alvas, e a cipsela associada a duas flores do disco podem identificar o gênero (Panero 2007). Ocorre em áreas antrópicas e campos limpos (Alves 2018b).

2.1. Parthenium hysterophorus L., Species Plantarum 2: 988. $1753 . \quad$ Fig. 3m-r

Erva, $50-65 \mathrm{~cm}$ alt.; ramos pilosos, presença de espinhos, entrenós 10-13 cm compr. Folhas discolores, pecioladas, pecíolo $0,5-3 \mathrm{~cm}$ compr., lâmina foliar 2-8 × 1,5-3,5 cm larg., tricomas estrigosos em ambas as faces, base atenuada, ápice atenuado ou agudo, margem inteira, nervação broquidródroma, nervuras principais 3. Capítulos ca. $3 \times 4 \mathrm{~mm}$ larg., receptáculo cônico, ca. 0,5 $\times 0,4 \mathrm{~mm}$; páleas ca. $2 \times 2 \mathrm{~mm}$, levemente conduplicadas, ápice truncado, glabra, nervura principal 1 , membranácea; brácteas involucrais ca. $2 \times 1-2 \mathrm{~mm}$, primeira e segunda série $2 \mathrm{~mm}$ alt., as externas ovadas, margem erosa, as internas 
circulares, margem inteira, base atenuada, ápice agudo nas externas, arredondado nas internas, membranácea, nervura principal 1, glabra na parte interna, estrigosa no ápice da face externa. Flores do raio férteis, corola ca. 0,5 × 0,5 mm larg., limbo arredondado, bilobado, ovário ca. 1,8 mm compr., obovoide, estilete ca. 0,5 mm compr.; flores do disco ca. 50, corola ca. $1 \times 0,5 \mathrm{~mm}$, anteras 4 , amarelas, ca. $1 \mathrm{~mm}$ compr., apêndice do conectivo ovado a arredondado, base arredondada, filete ca. 0,3 mm compr., ovário ca. 0,7 mm compr., filiforme, parede glabra, estilete ca. $0,5 \mathrm{~mm}$, ramos estigmáticos atrofiados. Cipsela ca. $2 \times 2 \mathrm{~mm}$, envolvida por uma bráctea involucral e duas flores do disco, marrom, parede e margem glabras; 2 extensões no ápice ca. 0,5 mm compr.

Material examinado: AMAZONAS: Rio Negro, fragmentos densos, XI.1933, fl. e fr., W.G. Herter 1638 (RB).

Material adicional examinado: ARGENTINA. PROVINCIA DE SAN LUIS: Sierra de las Quijadas, 6.III.1963, fl. e fr., A.E. Cocucci (RB 552393). BRASIL. ESPÍRITO SANTO: Presidente Kennedy, 28.X.2014, fl. e fr., M. Mayer (RB 657467). GOIÁS: Anápolis, 1.XII.1957, fl. e fr., Castellanos (R 155557). MINAS GERAIS: Carangola, 2.VIII.1989, fl. e fr., G.M. Barroso (RB 662533). RIO DE JANEIRO: Nova Iguaçu, morro Agudo, Rodilândia, 16.XI.2002, fl. e fr., J.P.P. Carauta 7187 (R). PARANÁ: Curitiba, Jardim Botânico, 11.I.1993, fl. e fr., O.S. Ribas \& J.Cordeiro 469 (MO). SÃO PAULO: Piracicaba, fazenda Areião, 29.III.1993, fl. e fr., K.D. Barretto et al. (RB 662449). Jundiaí, 18.XII.1970, fl. e fr., E. Santos et al. 2555 (R).

Nome popular: "Losna branca"

Parthenium hysterophorus é facilmente reconhecida por suas flores alvas, 2 séries de brácteas involucrais e 5 flores do raio. A planta está registrada para os estados do Tocantins, Alagoas, Bahia, Pernambuco, Goiás, Mato Grosso do Sul, Mato Grosso, Minas Gerais, Rio de Janeiro, São Paulo, Paraná (Alves 2018b) e Amazonas, sendo este último registrado pela primeira vez no presente estudo. É encontrada em áreas de pasto, perímetros antrópicos e bordas de mata. Floresce e frutifica entre março e novembro.

\section{Xanthium L.}

Arbusto; ramos eretos, lenhosos, ramificados, cilíndricos, sulcados. Folhas alternas, pecioladas, lobadas. Capítulos unissexuados, discoides; brácteas involucrais unisseriadas, livres nos masculinos e totalmente fundidas e com projeções uncinadas nos femininos. Flores masculinas com corola infundibuliforme, lacínias 5, deltoides, 5 anteras, amarelas; flores femininas nuas, ovário ovoide ou elipsoide. Cipselas elipsóides, negras; pápus ausente.

Xanthium possui nove espécies, das quais duas ocorrem no Brasil (The Plant List 2013; Alves 2018c). Distribui-se por toda a América (Davidse et al. 2018), ocorrendo em área antrópica, mata de igapó e matas abertas. O capítulo feminino bifloro com brácteas involucrais com projeções uncinadas constituem-se como característica identificadora do gênero na área de estudo.

3.1. Xanthium strumarium L. Species Plantarum 2: 987. 1753. Figura 3.

Fig. 3s-z

Arbusto, 1-2 m alt.; ramos esparsamente pilosos, entrenós 5-8,5 cm compr. Folhas concolores, pecioladas, pecíolo 2-7 cm, lâmina foliar 3-10 × 2-8,5 cm larg., tricomas estrigosos em ambas as faces, ápice agudo ou atenuado, base cordiforme ou atenuada, margem denteada, nervação craspedódroma, nervura principal 1 . Capitulescência espiciforme, axilar ou terminal. Capítulos masculinos ca. 0,5 × 0,5 cm, invólucro campanulado, receptáculo cônico, ca. $2 \times 2 \mathrm{~mm}$; páleas ca. $2 \times 0,5 \mathrm{~mm}$, oblanceoladas, ápice agudo, glabras, 3 nervuras principais, membranáceas; capítulos femininos $0,7-2 \times 1-2 \mathrm{~cm}$, invólucro elipsoide, páleas ausentes; brácteas involucrais do capítulo masculino $2-2,2 \times 1 \mathrm{~mm}$, oblongas, base truncada, ápice agudo, membranáceas, 3 nervuras principais, face interna e externa pilosa. Flores masculinas ca. 50 , corola ca. $2 \times 0,5 \mathrm{~mm}$, anteras ca. 1 compr., apêndice do conectivo deltoide, base do conectivo curto sagitada, filetes fundidos, ca. $0,8 \mathrm{~mm}$ compr., estilete atrofiado; flores femininas 2, ovário ca. $2 \mathrm{~mm}$ compr., ovoide a elipsoide, parede glabra, estilete ca. 2,5 mm compr., ramos estigmáticos ca. $1 \mathrm{~mm}$, ápice obtuso, castanhos. Cipselas ca. $12-15 \times 4 \mathrm{~mm}$, parede e margem glabra, carpopódio conspícuo; pápus ausente. Material examinado: AMAZONAS: Alvarãs, Rio Solimões, margem direita do lago de Alvarãs, 29.XI.1982, fl. e fr., I.L. Amaral et al. 676 (RB; INPA).

Material adicional examinado: BRASIL. CEARÁ: Jati, reservatório Atalho, 14.XI.2012, fl. e fr., F.F.S. Silva 602 (HUEFS). Jucás, Canafístula, 1994, fl. e fr., M. Luzenilda (EAC 21269). RIO GRANDE DO SUL: Caxias do Sul, São Virgílio, 9.III.2000, fl. e fr., A. Kegler 790 (NY). Marcelino Ramos, 2.III.1996, fl. e fr., J.A. Jarenkow 3102 (ESA). SANTA CATARINA: Apiúna, 17.I.2013, fl. e fr., B. Tribess 102 (FURB).

Xanthium strumarium pode ser facilmente reconhecida por suas folhas lobadas e seus capítulos masculinos com brácteas livres e os 
femininos com duas flores e projeções uncinadas. Amazonas, Bahia, Ceará, Minas Gerais, Rio de Janeiro, São Paulo, Paraná, Rio Grande do Sul e Santa Catarina figuram entre os estados com a presença da espécie (Alves 2018c). É encontrada em matas de igapó, áreas de cultivo e beira de estradas. Floresce e frutifica de janeiro a novembro.

\section{Chave de identificação dos gêneros da subtribo Helianthinae na Amazônia Legal brasileira}

1. Folhas do limbo inteiras. Pendúnculo do capítulo não inflado próximo ao ápice

4. Aldama

1'. Folhas do limbo pinapartidas. Pendúnculo do capítulo inflado próximo ao ápice 5. Tithonia

\section{Aldama La Llave.}

Ervas ou subarbustos, anuais ou perenes; ramos cilíndricos, sulcados, sublenhosos. Folhas alternas ou opostas; lâmina linear, oblonga, ovada, lanceolada ou elíptica. Capítulos radiados, solitários ou agrupados em dois ou três; brácteas involucrais em 2-4 séries, face externa pilosa ou estrigosa, conduplicadas; receptáculo plano ou convexo, paleáceo; páleas membranáceas, amarelas. Flores do raio neutras, amarelas, ápice 2-3 lobado; flores do disco bissexuadas, corola tubulosa, lacínias 5, deltoides, amarelas; anteras 5 , apêndice do conectivo ovoide ou deltoide; ramos estigmáticos recurvados, amarelos. Cipselas obovoides ou estreitamente obovoides, estriadas; pápus persistente, coroniforme, aristado.
As espécies apresentadas neste estudo pertenciam anteriormente ao gênero Viguiera Kunth. Através de estudos com DNA plastidial e dados morfolóficos, Schilling \& Panero (2011) observaram que as espécies da América do Sul emergiram na árvore filogenética próximas dos representantes de Aldama, levando ao reposicionamento das Viguiera sul-americanas para Aldama. O Brasil apresenta 36 espécies, seis delas ocorrendo na Amazônia Legal brasileira (Magenta 2018). As flores do raio neutras, folhas sésseis ou subsésseis, alternas e opostas no mesmo indivíduo e o pápus coroniforme são características que identificam o gênero na área de estudo. Ocorrem em área antrópica, florestas ombrófilas mistas, pastos, afloramentos rochosos, matas ciliares e cerrado (Magenta 2018).

\section{Chave de identificação das espécies de Aldana na Amazonia Legal Brasileira}

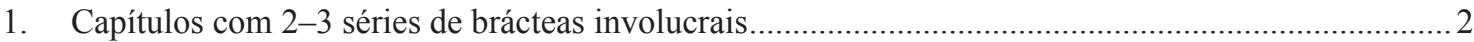

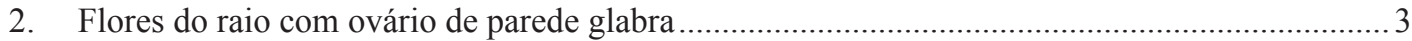

3. Ovário das flores do raio filiforme; ovário das flores do disco com parede totalmente glabra; cipsela não gibosa na porção central ............................................... 4.1. Aldama grandiflora

3'. Ovário das flores do raio obovoide; ovário das flores do disco com parede glabra de ápice estrigoso; cipsela gibosa na porção central 4.5. Aldama squalida

2'. Flores do raio com ovário de parede pilosa ou esparsamente pilosa

4. Folhas com nervação broquidódroma; páleas com ápice agudo; cipsela com parede totalmente pilosa 4.6. Aldama tuberosa

4'. Folhas com nervação acródroma; páleas com o ápice arredondado; cipsela com parede glabra e ápice estrigoso 4.2. Aldama kunthiana

1'. Capítulos com 4 séries de brácteas involucrais .5

5. Apêndice do conectivo deltoide; flores do disco com a parede do ovário glabra; folhas subsésseis; pápus com aristas iguais. 4.3. Aldama oblongifolia

5'. Apêndice do conectivo ovoide; flores do disco com a parede do ovário pilosa; folhas sésseis; pápus com aristas desiguais. 4.4. Aldama robusta

4.1. Aldama grandiflora (Gardner) E.E.Schill. \& Panero, Bot. J. Linn. Soc. 167(3): 323. 2011. Viguiera grandiflora Gardner, London J. Bot. 7: 404. 1848 .
Fig. 4a-h
Erva $35-80 \mathrm{~cm}$ alt.; ramos eretos, densamente hisurtos na base, esparsamente hisurtos em direção ao ápice, entrenós 3,5-5 cm. Folhas concolores, alternas, raramente opostas na base do caule, sésseis, 


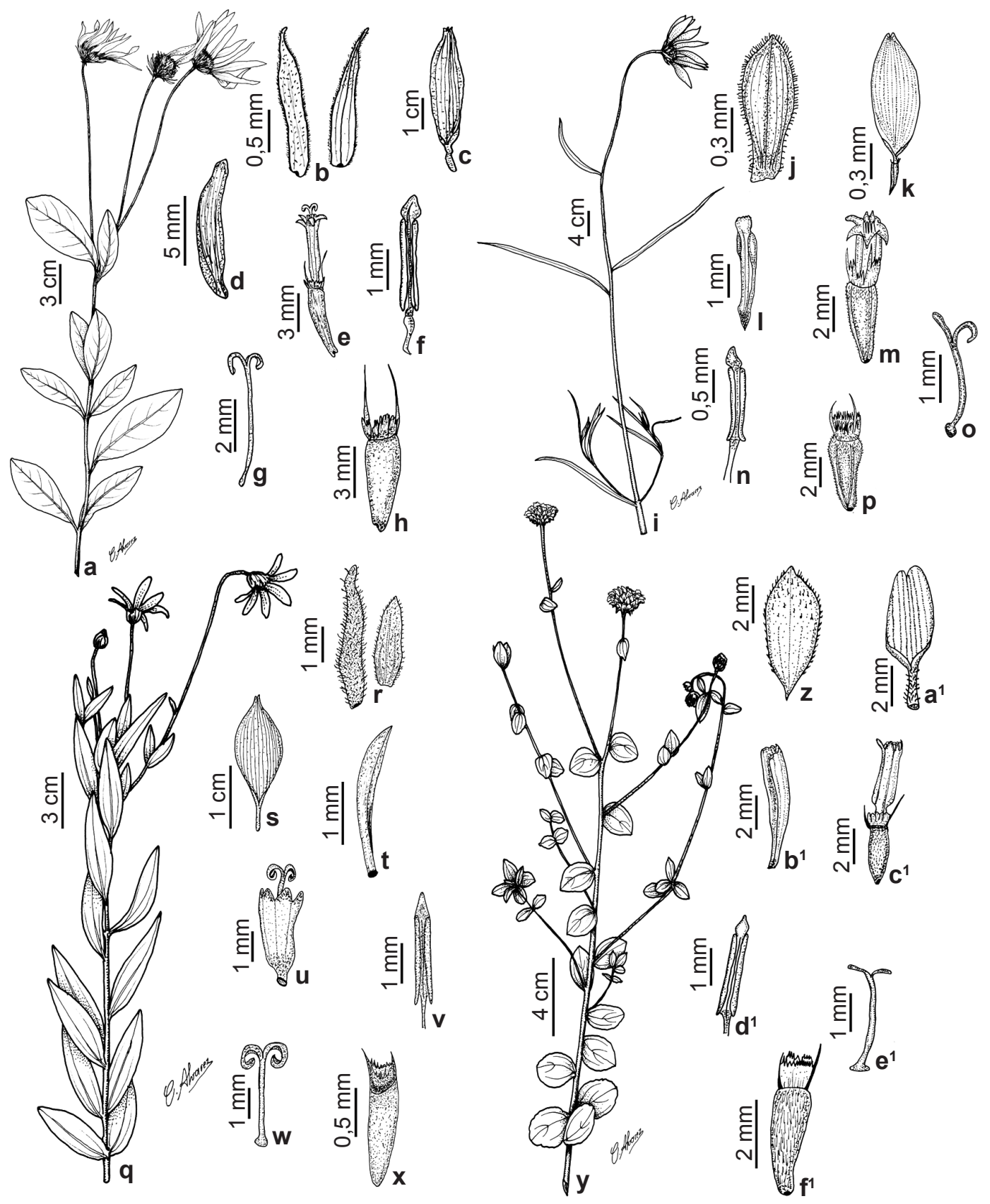

Figura 4-a-h. Aldama grandiflora - a. hábito; b. face externa (esquerda) e face interna da bráctea involucral (direita); c. flor do raio; d. pálea; e. flor do disco; f. antera; g. estilete e estigma; h. cipsela. i-p. Aldama kunthiana -i. hábito; j. bráctea involucral; k. flor do raio; 1. pálea; m. flor do disco; n. antera; o. estilete e estigma; p. cipsela. q-x. Aldama oblongifolia - q. hábito; r. brácteas involucrais; s. flor do raio; t. pálea; u. flor do disco; v. antera; w. estilete e estigma; x. cipsela. $\mathrm{y}-\mathrm{f}^{1}$. Aldama robusta - y. hábito; z. bráctea involucral; $\mathrm{a}^{1}$. flor do raio; $\mathrm{b}^{1}$. pálea; $\mathrm{c}^{1}$. flor do disco; $\mathrm{d}^{1}$. antera; $\mathrm{e}^{1}$. estilete e estigma; $\mathrm{f}^{1}$. cipsela. (a-h. G.M. Hastschbach \& J.M. Silva 5602; i-p. R.C. Forzza 6735; q-x. G.P. Silva et al. 4532; y- $\mathrm{f}^{1}$. C.A.S. Correia 38). (Ilustração: a,i,q,v. Carlos Alvarez; b-h,j-p,r-x,z-f ${ }^{1}$. Markus Campos).

Figure 4 - a-h. Aldama grandiflora - a. habit; b. outer involucral bract (left) and inner involucral bract (right); c. ray floret; d. palea; e. disc floret; f. anther; g. style and stigma; h. cypsela. i-p. Aldama kunthiana - i. habit; j. involucral bract; k. ray floret; 1. palea; m. disc floret; $\mathrm{n}$. anther; o. style and stigma; p. cypsela. q-x. Aldama oblongifolia - q. habit; r. involucral bract; s. ray floret; t. palea; u. disc floret; v. anther; w. style and stigma; x. cypsela. $\mathrm{y}-\mathrm{f}^{1}$. Aldama robusta $-\mathrm{y}$. habit; z. involucral bract; ${ }^{1}$. ray floret; $\mathrm{b}^{1}$. palea; $\mathrm{c}^{1}$. disc floret; $\mathrm{d}^{1}$. anther; $\mathrm{e}^{1}$. style and stigma; $\mathrm{f}^{1}$. cypsela. (a-h. G.M. Hastschbach \& J.M. Silva 5602; i-p. R.C. Forzza 6735; q-x. G.P. Silva et al. 4532; y- $\mathrm{f}^{1}$. C.A.S. Correia 38). (Illustration: a,i,q,v. Carlos Alvarez; b-h,j-p,r-x,z-f'. Markus Campos). 
lâmina 7-9 × 2,6-4,5 cm, elíptica ou largamente elíptica, faces abaxial e adaxial estrigosas, base arredondada ou atenuada, ápice arredondado ou agudo, margem denteada, nervação acródroma, nervuras principais 5. Capítulos solitários ou agrupados em 2-3, axilares ou terminais; $1,5-2$ $\times 2-2,5 \mathrm{~cm}$, invólucro campanulado, receptáculo convexo, ca. $1 \mathrm{~cm}$ compr.; páleas ca. 10-11 × 2 $\mathrm{mm}$, lanceoladas, ápice acuminado, glabras na face interna, estrigosas no ápice da face externa, nervuras principais $8-12$; brácteas involucrais bisseriadas, ca. 1,5-1,7 × 0,2 cm, linear-lanceoladas, margem ciliada, base truncada, série externa foliácea, interna membranácea, ápice agudo, nervuras principais $3-5$, face externa pilosa, face interna glabra e ápice estrigoso. Flores do raio 15, corola do raio verdadeira, ca. $5 \mathrm{~cm}$ compr., glabra em ambas as faces, levemente estrigosa na base; limbo estreito-elíptico, nervuras principais 18-20, ápice trilobado, ovário ca. $5 \mathrm{~mm}$ compr., filiforme, parede glabra; flores do disco 60-80, bissexuadas, corola ca. $6 \times 2 \mathrm{~mm}$, base e ápice estrigoso; anteras ca. $3,5 \mathrm{~mm}$, castanhas, apêndice do conectivo ovoide, base curto sagitada, filete ca. 1,5 mm compr., ovário ca. $6 \times 1 \mathrm{~mm}$, obovoide, parede e margem glabras, estilete ca. $5 \mathrm{~mm}$, estilopódio conspícuo, ramos estigmáticos ca. 1,2 mm, ápice truncado. Cipsela ca. 6-8 $\times 3 \mathrm{~mm}$, estreitamente obovoides, não gibosa, parede e margem glabras, carpopódio conspícuo; pápus ca. $1 \mathrm{~mm}$ compr., biaristado, aristas iguais ou desiguais, $2-3 \mathrm{~mm}$ alt.; escamas soldadas até o meio.

Material examinado: MATO GROSSO: $8 \mathrm{~km}$ ao sul da base de campo $12^{\circ} 49^{\prime}$ 'S, $51^{\circ} 46^{\prime} \mathrm{W}$, 13.IX.1968, fl. e fr., R.M. Harley. 1012 (NY). TOCANTINS: Arraias, 5-10 km da rod. para Paranã, 10.XI.1991, fl. e fr., G.M. Hatschbach \& J.M. Silva. 56012 (INPA).

Material adicional examinado: BRASIL. MATO GROSSO DO SUL: BR-262 a $40 \mathrm{~km}$ de Campo Grande, 9.IX.1994, fl. e fr., B. Dubs (ESA 1755).

Aldama grandiflora assemelha-se a Aldama squalida pelo tamanho e forma das folhas, mas se diferenciam pelas brácteas involucrais linearlanceoladas e a cipsela estreitamente obovoide em A. grandiflora (vs. brácteas involucrais ovallanceoladas e cipselas obovoides gibosas na porção central). A espécie é nativa do Brasil ocorrendo nos estados do Amazonas, Bahia, Distrito Federal, Goiás, Mato Grosso do Sul, Mato Grosso, Minas Gerais, Paraná (Magenta 2018) e Tocantins, sendo que neste último constitui-se como novo registro. Pode ser encontrada em manchas de cerrado e encostas rochosas. Floresce entre setembro e novembro.
4.2. Aldama kunthiana (Gardner) E.E. Schill. \& Panero, Bot. J. Linn. Soc. 167(3): 323. 2011. Viguiera kunthiana Gardner, London J. Bot. 7: 399. 1848.

Fig. 4i-p

Subarbusto 25-100 cm alt.; ramos eretos, esparsamente pilosos; entrenós 11-16 cm compr. Folhas concolores, opostas na base, alternas em direção ao ápice, sésseis, lâmina foliar $0,8-0,9 \times$ $0,2-0,3 \mathrm{~cm}$, linear ou estreitamente lanceolada, estrigosa em ambas as faces, base atenuada, ápice agudo, margem inteira, nervação acródroma, 3 nervuras principais. Capítulos solitários, terminais, ca. $0,9 \times 1 \mathrm{~cm}$, invólucro campanulado, receptáculo convexo, ca. $3 \times 4 \mathrm{~mm}$; páleas ca. $4,5 \times 1 \mathrm{~mm}$, obovais ou oblanceoladas, conduplicadas, ápice arredondado, eroso, esparsamente pilosa na face interna e externa, nervuras principais 7 ; brácteas involucrais bisseriadas, ca. $0,8 \times 0,2 \mathrm{~cm}$, oblonga ou ovada, margem ciliada, base truncada, foliácea, ápice agudo, oito nervuras principais, face externa estrigosa, face interna estrigosa no ápice. Flores do raio 10 , corola ca. 1,2-1,3 $\times 0,5 \mathrm{~cm}$, estrigosa na base, limbo elíptico, ca. 16 nervuras principais, ápice bi ou trilobado, ovário ca. 3,5 $\mathrm{mm}$ compr., filiforme a estreitamente obovoide, levemente tricostado; flores do disco 60-70, corola ca. $3 \times$ $1 \mathrm{~mm}$, base e ápice estrigoso, ca. 1,5 m compr., negras, apêndice do conectivo ovoide, base do conectivo curto sagitada, filete $0,5-0,7 \mathrm{~mm}$ compr., ovário ca. $4 \times 1,5 \mathrm{~mm}$, obovoide, parede estrigosa no ápice, estilete $2 \mathrm{~mm}$ compr., ramos estigmáticos ca. $0,5 \mathrm{~mm}$ compr., amarelo, ápice agudo. Cipsela ca. 4,7-5 × $2 \mathrm{~mm}$, obovoide, tetracostada, não gibosa, margem levemente dilatada, parede glabra e ápice estrigoso, margem curto-ciliada; pápus ca. $2,5 \mathrm{~mm}$, biaristado, aristas ligeiramente desiguais, a maior com ca. $2,5 \mathrm{~mm}$; escamas soldadas até o meio.

Material examinado: TOCANTINS: Palmeirópolis, Serra Dourada, 12.XI.1991, fl. e fr., G.M. Hatschbach \& J.M. Silva (INPA 195534).

Material adicional examinado: BRASIL. GOIÁS: Água Fria de Goiás, $15^{\circ} 01^{\prime} 33^{\prime \prime} \mathrm{S}, 47^{\circ} 36^{\prime} 01^{\prime} \mathrm{W}, 31 . X .2012$, fl. e fr., B. Loeuille et al. 737 (RB). Alto Paraíso de Goiás, chapada dos Veadeiros, estrada de terra Alto Paraíso-São Jorge, 20.VII.2013, fl. e fr., B. Loeuille et al. 842 (RB). Cocalzinho de Goiás, areias, ca. $20 \mathrm{~km}$ da BR-414, 23.XI.2013, fl. e fr., R.C. Forzza et al. 6735 (RB).

Aldama kunthiana possui o hábito semelhante ao de Aldama tuberosa por suas folhas lanceoladas, diferenciando-se na nervação acródroma, brácteas com ápice arredondado e cipsela com ápice estrigoso em A. kunthiana (vs. nervação broquidódroma, brácteas com ápice agudo e cipselas com parede 
pilosa). A espécie ocorre em Distrito Federal, Goiás e Minas Gerais (Magenta 2018). O presente estudo revelou registro novo para o estado do Tocantins. São encontradas principalmente no cerrado em encostas de morro, solos arenosos e beira de estradas. Floresce e frutifica entre julho e dezembro.

4.3. Aldama oblongifolia (Gardner) E.E. Schill. \& Panero, Bot. J. Linn. Soc.167: 324. 2011. Viguiera oblongifolia Gardner, London J. Bot. 7: 402. 1848.

Fig. $4 \mathrm{q}-\mathrm{x}$

Erva 40-100 cm alt.; ramos eretos, densamente pilosos na base, esparsamente pilosos em direção ao ápice, entrenós 2-6 cm compr. Folhas concolores, opostas na base e alternas em direção ao ápice, subsésseis, pecíolo 1-3 mm, lâmina foliar 1,5-12,5 $\times 0,4-4 \mathrm{~cm}$, de oblonga ou elípitica, face adaxial e abaxial esparsamente pilosa ou pilosa, às vezes escabra, base arredondada ou obtusa, ápice agudo, obtuso ou às vezes acuminado, margem inteira a levemente serreada, nervação acródroma, nervuras principais 3. Capítulos solitários ou agrupados em dois ou três capítulos terminais, $0,5-2 \times 0,5-2$ $\mathrm{cm}$, invólucro campanulado, receptáculo plano ou convexo 0,2-0,4 mm compr.; páleas $12-15 \times 2-3$ $\mathrm{mm}$, oblanceolada, ápice truncado ou acuminado, face interna e externa estrigosa, nervuras principais 5-7; brácteas involucrais em 4 séries, 1,1-2 $\times$ $0,2-0,3 \mathrm{~cm}$, ovada-lanceolada, elíptica ou estreitoelíptica, margem ciliada, base truncada, foliácea, ápice agudo ou acuminado, face externa pilosa, face interna glabra ou com parte superior estrigosa. Flores do raio 8 , ca. $2,5 \mathrm{~cm}$, face adaxial glabra, face abaxial esparsamente estrigosa nas nervuras, limbo elíptico, 12-16 nervuras principais, ápice bilobado, ovário ca. $1 \mathrm{~mm}$, filiforme, parede glabra; flores do disco ca. 40, corola ca. 5-6 $\times 1,5 \mathrm{~mm}$, base e ápice estrigoso, anteras ca. $3 \mathrm{~mm}$ compr., apêndice do conectivo deltoide, base curto sagitada, filete ca. $1,5 \mathrm{~mm}$, ovário ca. $5 \mathrm{~mm}$, obovoide, parede glabra, margem curto ciliada, estilete $4-5 \mathrm{~mm}$, ramos estigmáticos ca. $1 \mathrm{~mm}$, ápice truncado, recurvados, amarelo. Cipsela 5-6 mm, obovoide, esparsamente pilosa, não gibosa na base, margem glabra; pápus ca. $1,5 \mathrm{~mm}$, aristas iguais, escamas soldadas.

Material examinado: ACRE: Bujari, $\mathrm{km} 99$ da rod. Cuiabá-Porto Velho, 24.XI.1982, fl. e fr., C.S. Rosário 493 et al. (MG). TOCANTINS: Almas, à cerca de 5,5 $\mathrm{km}$ da estrada de Almas em área à esquerda, 29.I.2014, fl. e fr., B.M.T.W. et al. 6715 (CEN). Luciára, 1-5 km oeste da BR-158, 17.X.1985, fl. e fr., W. Thomas et al. (INPA 150989); Chapada dos Guimarães, BR-251 entre
Cuiabá e Chapada dos Guimarães, 22.XI.1982, fl. e fr., C.S. Rosário 459 et al. (MG).

Material adicional examinado: BRASIL. GOIÁS: Minacu, 14.XII.2000, fl. e fr., G.P. Silva et al. 4532 (IAN); rod. Belém-Brasília, fazenda Americana, 9.I.1961, fl. e fr., L. Emygdio 1896 (R); estrada Xavantina-Cachimbo, BR-158, km 244, 5.XII.1967, fl. e fr., J. Bertoldo 3390 (IAN).

A espécie possui 4 séries de brácteas involucrais, semelhante a Aldama robusta. Diferencia-se desta, contudo, pelas folhas subsésseis, geralmente oblongas e apêndice do conectivo deltoide $v s$. folhas sésseis, geralmente ovadas e apêndice do conectivo ovoide. Aldama oblongifolia ocorre no Brasil, tendo registros para os estados do Ceará, Goiás, Maranhão, Mato Grosso, Minas Gerais e Pará (Magenta 2018) e Bahia (Alves et al. 2015). Trata-se de uma nova ocorrência para o estado do Acre. Está presente em beiras de estrada, manchas de cerrado e solos arenosos ou pedregosos. Aldama oblongifolia floresce e frutifica o ano todo.

4.4. Aldama robusta (Gardner) E.E.Schill. \& Panero, Bot. J. Linn. Soc. 167(3): 324. 2011. Viguiera robusta Gardner, London J. Bot. 7: 403. 1848.

Fig. $4 \mathrm{y}-\mathrm{f}^{1}$

Erva ou subarbusto $80-200 \mathrm{~cm}$ alt.; ramos eretos, densamente pilosos na base e esparsamente pilosos em direção ao ápice, levemente sulcados, entrenós 1-7 cm. Folhas levemente discolores ou discolores, inferiores opostas, superiores alternas, sésseis, lâmina foliar $0,7-5 \times 0,5-2,5 \mathrm{~cm}$, ovada ou oblonga, às vezes elíptica, face abaxial densamente pilosa; face adaxial estrigosa, base arredondada, ápice arredondado ou agudo, margem serreada ou crenada, nervação acródroma, nervuras principais 3. Capítulos solitários ou reunidos em 2 ou 3 terminais, ca. 1-1,5×1 cm, invólucro campanulado, receptáculo convexo, ca. $5 \times 8 \mathrm{~mm}$; páleas ca. $8 \times 2$ $\mathrm{mm}$, oblongas, ápice arredondado, eroso, estrigosas no ápice da parte interna, nervuras principais 9 , amarelas, membranáceas; brácteas involucrais em 4 séries, $0,5-0,7 \times 0,3-0,4 \mathrm{~cm}$, obovoides, margem pilosa, base aguda ou arredondada, foliáceas, ápice agudo ou arredondado, mucronado, nervuras principais 3 , face externa esparsamente pilosa e ápice estrigoso, face interna estrigosa no ápice. Flores do raio 10-12, corola ca. $8 \times 2-3 \mathrm{~mm}$, base pilosa, elíptica, nervuras principais 10 , ápice bi ou trilobado, ovário ca. $4 \mathrm{~mm}$ compr., filiforme, levemente tricostado, glabro; flores do disco 70115 , corola ca. $6 \times 1 \mathrm{~mm}$, base e ápice estrigosos, 
anteras 2,8-3 mm compr., apêndice do conectivo ovoide, base curto sagitada, filete ca. $1,5 \mathrm{~mm}$ compr., ovário ca. 3,5 mm compr., obovado, piloso, estilete ca. 3,5 mm compr., ramos estigmáticos ca. $0,5 \mathrm{~mm}$ compr., ápice truncado, amarelo. Cipsela ca. $3 \times 1 \mathrm{~mm}$, obovoide, levemente tricostada, não gibosa na base, densamente pilosa, margem glabra, carpopódio conspícuo; pápus ca. $2 \mathrm{~mm}$ compr., 2 aristas desiguais, a maior com ca. $2 \mathrm{~mm}$, a menor com ca. 1,5 mm compr., escamas livres, soldadas até o meio, ou até o ápice.

Material examinado: TOCANTINS: Mateiros, região do Jalapão, nas proximidades do riacho Formiga, 6.V.2001, fl. e fr., Simpson 56 (UB).

Material adicional examinado: BRASIL. BAHIA: chapadão ocidental da Bahia, 28.IV.1980, fl. e fr., R.M. Harley 21911 (RB). DISTRITO FEDERAL: 1.V.1966, fl. e fr., H.S. Irwin et al. (INPA 108128). Brasília, 1.V.1980, fl. e fr., J.H. Kirkbride Jr. (INPA 12318); Parque das Sucupiras, 18.IV.2005, fl. e fr., C.A.S. Correia 38. (INPA ); BR-020 entre Brasília e Sobradinho, 3.IV.1980, fl. e fr., T. Plowman 9976 (INPA). MINAS GERAIS: Piedade do Rio Grande, Carvão, 7.IV.2016, fl. e fr., M. Sobral et al. 15856 (RB).

Aldama robusta ocorre nos estados do Tocantins, Bahia, Distrito Federal, Goiás, Mato Grosso do Sul, Minas Gerais, Rio de Janeiro, São Paulo e Paraná (Magenta 2018). Pode ser encontrada em bordas de mata, fazendas, beiras de estradas, manchas de cerrado e solo arenoso. A floração e frutificação acontece entre abril e maio.

4.5. Aldama squalida (S. Moore) E.E. Schill. \& Panero, Bot. J. Linn. Soc. 167(3): 325. 2011. Viguiera squalida S. Moore, J. Bot. 37. 1904.

Fig. 5a-h

Erva ou subarbusto $50-150 \mathrm{~cm}$ alt.; ramos eretos, pilosos, sulcados, cilíndricos, entrenós $1,5-5,5 \mathrm{~cm}$ compr. Folhas concolores, alternas ou opostas, sésseis, lâmina foliar 2,5-12 × 0,5-4,5 $\mathrm{cm}$, ovada ou elíptica, face abaxial glabra ou pilosa, às vezes estrigosa, base aguda ou cuneada, ápice agudo, margem inteira, às vezes serreada próximo ao ápice, nervação acródroma. Capítulos solitários, às vezes agrupados em dois capítulos, terminais ou axilares, ca. 1,5-1,7 × 1,2 cm, invólucro campanulado, receptáculo convexo, ca. $4 \times 5 \mathrm{~mm}$; páleas ca. $7 \times 2 \mathrm{~mm}$, oblanceoladas, ápice obtuso, mucronado, face interna glabra, face externa com ápice estrigoso, nervuras principais 9 ; brácteas involucrais $2-3$ séries, ca. $0,9 \times 0,2 \mathrm{~cm}$, oval-lanceolada, margem ciliada, base truncada, foliácea, ápice agudo, nervuras principais 3 , face externa pilosa na nervura central, estrigosa no ápice, face interna estrigosa no ápice. Flores do raio 10 , corola ca. $2-2,3 \times 0,5 \mathrm{~cm}$, limbo elíptico a oblongo, nervuras principais 16 , bi ou trilobado, ovário ca. $5 \mathrm{~mm}$ compr., obovoide, levemente tricostado, glabro; flores do disco 50-110, corola ca. $4 \times 2 \mathrm{~mm}$ larg., base e ápice estrigosos, anteras ca. 2,5 mm compr., apêndice do conectivo ovoide, base curto sagitada, filete ca. $1 \mathrm{~mm}$ compr., ovário ca. $4 \times 1 \mathrm{~mm}$ larg., obovoide, giboso, estrigoso próximo ao ápice, estilete ca. $3 \mathrm{~mm}$ compr., ramos estigmáticos ca. 1,2 $\mathrm{mm}$ compr., ápice agudo, amarelo. Cipsela ca. 4-4,2 2 mm larg., obovoide, levemente tetracostada, gibosa na porção central, estrigosa próximo ao ápice, margem glabra; pápus ca. $3 \mathrm{~mm}$, biaristado, aristas iguais ou desiguais, escamas soldadas até o ápice ou próximo.

Material examinado: MATO GROSSO: PoxoréoSangradouro, km 25, 30.X.1976, fl. e fr., P. Assunção 254 et al. (INPA); Chapada dos Guimarães, cachoeira Véu de Noiva, fl. e fr., 14.X.1973, G.T. Prance et al. (INPA 42448).

Material adicional examinado: BRASIL. GOIÁS: Itumbiara, BR-153, km 637, 3.XI.2001, fl. e fr., $M$. Neto 308 et al. (RB). Piranhas, serra de São João, 06.XI.2012, fl. e fr., B. Loeuille 773 et al. (RB). MATO GROSSO DO SUL: Rio Brilhante, BR-267, entroncamento, 22.X.1970, fl. e fr., G.M. Hatschbach 25040 (INPA). São Gabriel do Oeste, BR-163, Campo Grande-Rondonópolis, 11.XII.2012, fl. e fr., B. Loeuille 790 et al. (RB).

A espécie foi encontrada na Bolívia (Wood et al. 2011) e no Brasil nos estados do Tocantins, Mato Grosso, Mato Grosso do Sul, Goiás, Minas Gerais e Paraná (Magenta 2018). Em geral ocorrem em solos arenosos, cerrado, beirasde estrada, bordas de cultivo, campos e campos de brejo. A planta floresce e frutifica entre outubro e dezembro.

4.6. Aldama tuberosa (Griseb.) E.E. Schill. \& Panero, Bot. J. Linn. Soc. 167(3): 325. 2011. Viguiera tuberosa Griseb., Abh. Königl. Ges. Wiss. Göttingen 24: 192. 1879.

Fig. 5i-p

Erva 50-100 cm alt.; ramos eretos, esparsamente pilosos, entrenós 8-10 cm compr. Folhas levemente discolores, alternas na base e ápice, decussadas na porção mediana, sésseis, lâmina foliar 5-12 × 0,5-1 cm, oblonga ou estreitoelíptica, face abaxial pilosa, face adaxial estrigosa, base atenuada, ápice agudo, margem inteira, três nervuras principais. Capítulos solitários, terminais, ca. $1 \times 1,5 \mathrm{~cm}$, invólucro campanulado, receptáculo ligeiramente convexo, ca. $3 \times 4 \mathrm{~mm}$; páleas ca. $7 \times 1 \mathrm{~mm}$, estreitamente oblanceolada, ápice agudo, glabra em ambas as faces, nervuras 


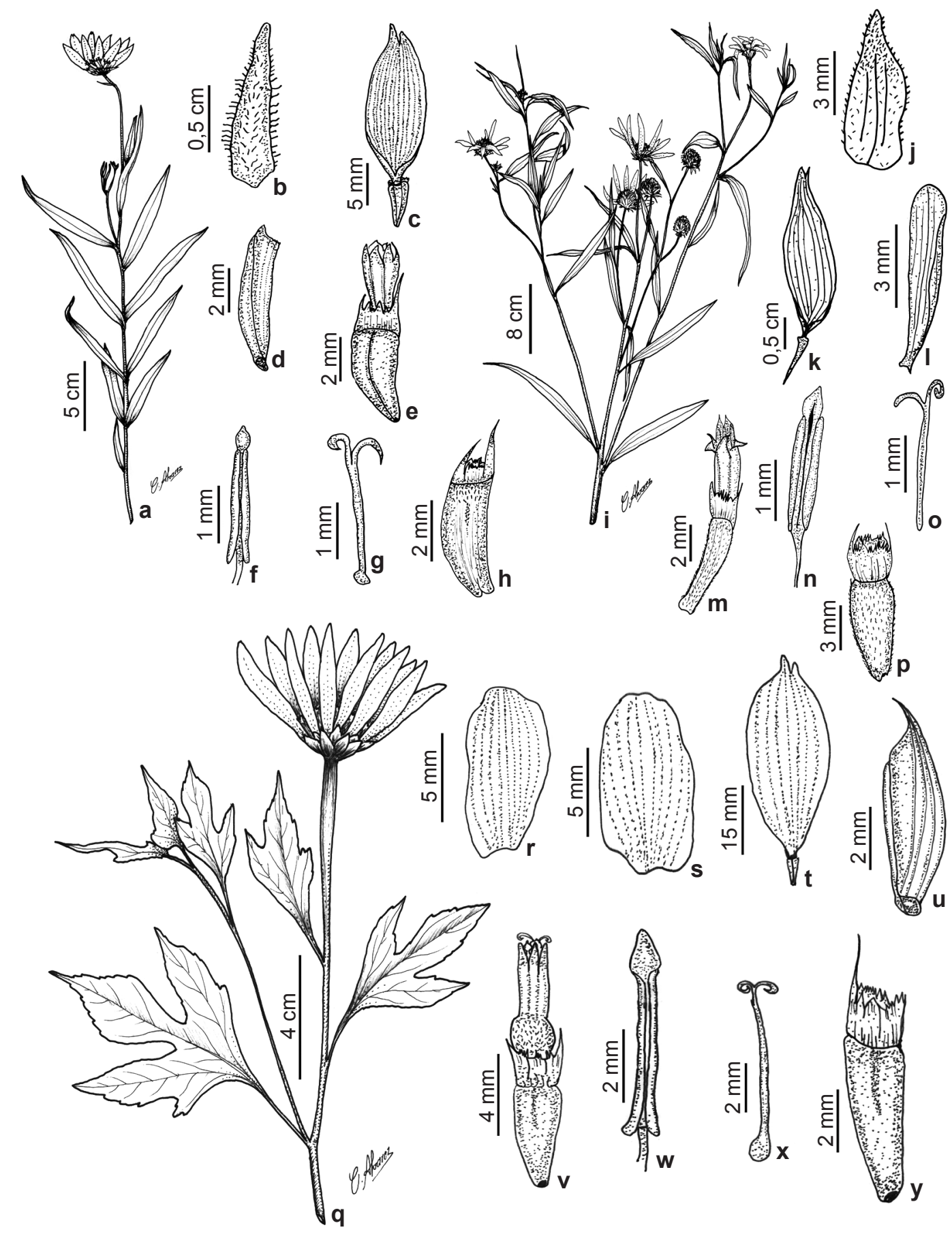

Figura 5 - a-h. Aldama squalida - a. hábito; b. bráctea involucral; c. flor do raio; d. pálea; e. flor do disco; f. antera; g. estilete e estigma; h. cipsela. i-p. Aldama tuberosa - i. hábito; j. bráctea involucral; k. flor do raio; 1. pálea; m. flor do disco; n. antera; o. estilete e estigma; p. cipsela. q-y. Tithonia diversifolia - q. hábito; r-s. brácteas involucrais; t. flor do raio; u. paléa; v. flor do disco; w. antera; x. estilete e estigma; y cipsela. (a-h. G.T. Prance (INPA 42448); i-p. L.B. Smith 11018; q-y. C.V.V. Souza 08). (Ilustração: a,i,q. Carlos Alvarez; b-h,j-p,r-y. Markus Campos).

Figure 5 - a-h. Aldama squalida - a. habit; b. involucral bract; c. ray floret; d. palea; e. disc floret; f. anther; g. style and stigma; h. cypsela. i-p. Aldama tuberosa - i. habit; j. involucral bract; k. ray floret; 1 . palea; $\mathrm{m}$. disc floret; $\mathrm{n}$. anther; o. style and stigma; p. cypsela. q-y. Tithonia diversifolia - q. habit; r-s. involucral bracts; t. ray floret; u. palea; v. disc floret; w. anther; x. style and stigma; y. cypsela. (a-h. G.T. Prance (INPA 42448); i-p. L.B. Smith 11018; q-y. C.V.V. Souza 08). (Illustration: a,i,q. Carlos Alvarez; b-h,j-p,r-y. Markus Campos). 
principais 8; brácteas involucrais em 2 séries, ca. $7 \times 2 \mathrm{~mm}$, oval-lanceolada, margem ciliada, base truncada, foliácea, ápice agudo, nervura principal 1, estrigosa na face externa e no ápice da parte interna. Flores do raio 14 , corola ca. $2 \times 0,5 \mathrm{~cm}$ larg., esparsamente pilosa na base, glabra em direção ao ápice, limbo estreito-elíptico, nervuras principais 9, ápice bilobado, às vezes trilobado, ovário ca. 5-6 mm compr., filiforme, parede pilosa; flores do disco 50-60, corola ca. $4 \times 1 \mathrm{~mm}$ larg., base e ápice estrigoso, anteras ca. 2,5 mm compr., apêndice do conectivo ovoide, base curto sagitada, filete ca. 1,2 mm compr., ovário ca. $5 \mathrm{~mm}$ compr., linear, parede pilosa, margem ciliada, estilete ca. 2,5 mm compr., ramos estigmáticos ca. 0,8 mm compr., ápice truncado, amarelo. Cipsela ca. 5,5-6 $\times 2 \mathrm{~mm}$, estreitamente obovoide, parede glabra a densamente pilosa, não gibosa na porção central, margem ciliada a esparsamente ciliada; pápus ca. 1,5 mm compr., biaristado, aristas levemente desiguais, escamas soldadas até o ápice.

Material examinado: MATO GROSSO: fazenda Congonha, 22.X.1980, fl. e fr., P.P. Furtado et al. 17241 (RB).

Material adicional examinado: BRASIL. RIO GRANDE DO SUL: Alegrete, 25.X.2012, fl. e fr., $B$. Loeuille 719 et al. (RB). SANTA CATARINA: CaçadorCuritibanos, $11 \mathrm{~km}$ ao sudeste de caçador, 8.II.1957, fl. e fr., L.B. Smith 11018 (NY).

Aldama tuberosa é facilmente reconhecida por suas folhas decussadas na porção mediana. No Brasil, a espécie encontra-se nos estados do Mato Grosso, Mato Grosso do Sul, Paraná, Rio Grande do Sul e Santa Catarina (Magenta 2018). Encontrase em solo arenoso, fazendas e afloramentos rochosos. Possui flores e frutos no mês de outubro.

\section{Tithonia Desf. ex Juss.}

Arbusto; ramos eretos, cilíndricos, sulcados, sublenhosos ou lenhosos. Folhas pecioladas, pinatipartidas. Pedúnculo inflado na base da inflorescência. Capítulos radiados, invólucro campanulado, brácteas involucrais 3-4 séries, foliáceas. Flores do raio com corola do raio verdadeira, neutras, amarelas, bilobadas; flores do disco bissexuadas, tubulosas, lacínias 5, deltoides, amarelas, anteras 5, ovário obovado. Cipselas obovoides; pápus coroniforme.

Tithonia possui 23 espécies, distribuindo-se por toda a América (Davidse et al. 2018; The Plant List 2013). O Brasil apresenta duas espécies, ambas naturalizadas (BFG 2018). A base do pendúnculo do capítulo inflado, flores do raio neutras e pápus coroniforme identificam o gênero para a área de estudo. Ocorrem em áreas antrópicas, matas abertas e beira de estradas (BFG 2018).

5.1. Tithonia diversifolia (Hemsl.) A. Gray, Proc. Amer. Acad. Arts 19(1): 5. 1884. Mirasolia diversifolia Hemsl., Biol. Cent.-Amer., Bot. 2(8): 168, pl. 47. 1881.

Fig. 5q-y

Arbusto, 1-2 m alt.; ramos pilosos ou esparsamente pilosos. Folhas discolores, alternas, peciolo 0,5-3 cm compr., lamina foliar 4-10 $\times$ 2,3-8 cm larg., face adaxial estrigosa, face abaxial estrigosa com maior densidade nas nervuras, base atenuada, ápice agudo ou acuminado, margem serreada, nervação camptódroma, nervuras principais 5. Capítulos solitários, terminais, 2,5-2,8 $\times 1,7-2$, receptáculo cônico ou hemisférico, ca. $0,7 \times 0,8 \mathrm{~cm}$; páleas ca. $10 \times 3 \mathrm{~mm}$, obovadas, conduplicadas, ápice agudo, glabras, ca. 15 nervuras principais, membranáceas, amarelas; brácteas involucrais 3-4 séries, $1-1,5 \times 0,5-0,7$ $\mathrm{cm}$, primeira série ca. $0,8 \mathrm{~cm}$ alt., segunda e terceiras series ca. 0,9 cm alt., ovada, margem oblonga, base truncada, foliácea, ápice acuminado ou arredondado, 10-15 nervuras principais, glabra em ambas as faces. Flores do raio 15, corola 3,5-4 $\times 1-1,2 \mathrm{~cm}$, levemente estrigosas na base, limbo elíptico, ca. 20 nervuras, ovário ca. $0,6 \mathrm{~cm}$ compr., parede estreitamente obovoide, tricostada; flores do disco ca. 150 , corola $7 \times 2 \mathrm{~mm}$, tubulosas, base estrigosa, apêndice do conectivo ovado, base do conectivo curto sagitada, filete ca. $2 \mathrm{~mm}$ compr., ovário ca. $6 \mathrm{~mm}$ compr., parede glabra ou pilosa, estilete ca. $8 \mathrm{~mm}$, ramos estigmáticos ca. $1 \mathrm{~mm}$, ápice agudo, amarelo. Cipselas ca. 5-6 × $2 \mathrm{~mm}$, parede glabra ou pilosa, margem glabra, carpopódio conspícuo; pápus 2-5 mm compr., duas aristas iguais ou uma destacada de até $5 \mathrm{~mm}$ compr.; escamas livres ou soldadas até o meio.

Material examinado: AMAZONAS: Manaus, campus do INPA, 19.XI.2004, fl. e fr., C.G.B. Lima 39 (INPA); comunidade Caioé, 13.X.2009, fl. e fr., C.C.V. Souza 8 (INPA). PARÁ: Cametá, Porto Grande, na beira da estrada, 21.I.2017, fl. e fr., M.M. Campos 43 (MG). Santa Izabel, estrada para a comunidade de Conceição de Itá, 29.IX.2012, fl. e fr., D.B. Brandão et al. 01 (MFS). RONDÔNIA: Porto Velho, lixão do hospital Sta. Marcelina, 18.II.2011, fl. e fr., E.B.R. Tomasi 01 (RON 2264).

Material adicional examinado: BRASIL. BAHIA: Morro do chapéu, terreno ao lado do alojamento do CPRM, 24.III.2013, fl. e fr., M. Alves \& R.L. Borges 139 (ALCB).

Nomes populares: "Margaridão"; "Boldo". 
Tithonia diversifolia possui o pendúnculo inflado próximo ao ápice, além de ser um arbusto o que a difere das espécies de Aldama que ocorrem na área. Está presente em quase todos os estados brasileiros, já que é uma espécie introduzida (BFG 2018). A espécie é encontrada em áreas antrópicas, pastos, bordas de floresta, sendo considerada ruderal. Floresce e frutifica o ano inteiro.

\section{Agradecimentos}

Agradecemos à CAPES, o financiamento; ao Museu Paraense Emilio Goeldi, a concessão à utilização dos espaços institucionais; ao desenhista Carlos Alvarez, as ilustrações; e ao curador do herbário MG, as suas valiosas contribuições.

\section{Referências}

Alves M (2018a) Ambrosia. In: Flora do Brasil 2020 em construção. Instituto de Pesquisas Jardim Botânico do Rio de Janeiro. Disponível em < http:// floradobrasil.jbrj.gov.br/reflora/floradobrasil/ FB15947>. Acesso em 1 maio 2018.

Alves M (2018b) Parthenium. In: Flora do Brasil 2020 em construção. Instituto de Pesquisas Jardim Botânico do Rio de Janeiro. Disponível em $<$ http:// floradobrasil.jbrj.gov.br/reflora/floradobrasil/ FB16232>. Acesso em 1 maio 2018.

Alves M (2018c) Xanthium. In: Flora do Brasil 2020 em construção. Instituto de Pesquisas Jardim Botânico do Rio de Janeiro. Disponível em $<$ http:// floradobrasil.jbrj.gov.br/reflora/floradobrasil/ FB80771>. Acesso em 1 maio 2018.

Alves M \& Roque N (2016) Flora da Bahia: Asteraceae - Tribo Heliantheae. Sitientibus série Ciências Biológicas 16: 1- 63.

Alves M, Santana FA \& Roque N (2015) New records of thirteen Asteraceae from state of Bahia, Brazil. Check List 11: 1-5.

Anderberg AA, Baldwin BG \& Bayer RG (2007) Compositae. In: Kubitzki K (ed.) The families and genera of vascular plants VIII: flowering plants. Eudicots: Asterales. Springer, New york. Pp. 61-576.

BFG - Brazil Flora Group (2018) Brazilian Flora 2020: Innovation and collaboration to meet Target 1 of the Global Strategy for Plant Conservation (GSPC) Rodriguésia 69: 1513-1527.

Bringel Jr JBA \& Cavalcanti TB (2009) Heliantheae (Asteraceae) na bacia do Rio Paranã (Goiás, Tocantins), Brasil. Rodriguésia 60: 551-580.

Davidse G, Sousa Sánchez M, Knapp S \& Chiang Cabrera F (2018) Asteraceae. In: Davidse G, Sousa Sánchez M, Knapp S \& Chiang Cabrera F (eds.) F1. Mesoamer. Vol. 5(2): i-xix. Missouri Botanical Garden, St. Louis. Pp. 1-608.

Funk V, Hollowell T, Berry P, Kelloff C \& Alexander SN (2007) Checklist of the plants of the Guiana Shield
(Venezuela: Amazonas, Bolivar, Delta Amacuro, Guyana, Surinam, French Guiana). Contributions from the United States National Herbarium 55: 1-580.

Funk VA, Susanna A, Stuessy TF \& Robinson H (2009) Classification of Compositae. In: Funk VA, Susanna A, Stuessy TF \& Bayer RJ (eds.) Systematics, evolution, and biogeography of Compositae. International Association for Plant Taxonomy. Institute of Botany. University of Vienna, Rennweg 14, Vienna. 1030p.

Gonçalves GE \& Lorrenzi H (2011) Morfologia vegetal: organografia e dicionário ilustrado de morfologia das plantas vasculares. $2^{\mathrm{a}} \mathrm{ed}$. Instituto Plantarum, Nova Odessa. 512p.

IBGE - Instituto Brasileiro de Geografia e Estatística (2017) Amazônia Legal. Disponível em < https:// ww2.ibge.gov.br/home/geociencias/geografia/ amazonialegal.shtm? $\mathrm{c}=2>$. Acesso em 12 janeiro 2017.

Jorgensen PM \& Nee (2014) Catálogo de las plantas vasculares de Bolivia, Monographs in systematic botany from the Missouri Botanical Garden. Missouri Botanical Garden Press, Saint Louis. 1744p.

Magenta MAG (1998) As subtribos Ambrosiinae, Galinsoginae e Coreopsidinae (HeliantheaeAsteraceae) no estado de São Paulo. Instituto de Biociências, São Paulo. 134p.

Magenta MAG (2018) Aldama. In: Flora do Brasil 2020 em construção. Instituto de Pesquisas Jardim Botânico do Rio de Janeiro. Disponível em <http://floradobrasil. jbrj.gov.br/reflora/floradobrasil/FB124408>. Acesso em 1 maio 2018.

Mondin CA (2007) Novos registros de Heliantheae cass. (Asteraceae) no Brasil. Vol. 21, nº 4. Acta Botânica Brasilica, São Paulo. Pp. 993-1000.

Nakajima JN \& Semir J (2001) Asteraceae do Parque Nacional da serra da Canastra, Minas Gerais, Brasil. Revista Brasileira de Botânica 24: 471-478.

Panero JL (2007 [2006]) Tribe Heliantheae Cass. In: Kubitzki K (ed.) The families and genera of vascular plants. Flowering plants. Eudicots: Asterales. Vol. 8. Springer, Berlin. Pp. 440-477.

Panero JL, Freire SE, Espina LA, Crozier BS, Barboza GE \& Cantero JJ (2014) Resolution of deep nodes yields an improved back bone phylogeny and new basal lineage to study early evolution of Asteraceae. Elservier 80: 43-53.

Radford AE, Dickson WC, Massey JR \& Bell CR (1974) Vascular plant systematics. Harper \& Row, New York. 891p.

Robinson H (1981) A revision of the tribal and subtribal limits of the Heliantheae (asteraceae). Smithsonian Institution Press, Washington. 106p.

Roque N \& Bautista H (2008) Asteraceae: caracterização e morfologia. EDUFBA, Salvador. 73p.

Santos JUM (2001) O gênero Aspilia Thou. no Brasil. Museu paraense Emilio Goeldi. Vol. 1. Ed. Funtec, Belém. Pp. 40-45. 
Schilling EE \& Panero JL (2011) A revised classification of subtribe Helianthinae (Asteraceae: Heliantheae) II. Derived lineages. Botanical Journal of the Linnean Society 167: 311-331.

Silva GAR \& Santos JUM (2010) Novos registros de espécies da subtribo Ecliptinae (Heliantheae - Asteraceae) para a Amazônia brasileira. Acta Amazonica 40: 499-508.

Ter steege H, Pitman N, Sabatier N, Castellanos H, Holt PVD, Daly DC, Silveira M, Philipps O, Vasquez R, Andel TV, Duivenvoorden J, Oliveira AA, Ek R, Lilwah R, Thomas R, Essen JV, Baider C, Maas P, Mori S, Terborgh J, Vargas PN, Mogollón H \& Morawtez W (2003) A spacial modelo of tree $\alpha$-diversity and -density for the Amazon. Biodiversity and conservation 12: 2255-2277.
The Plant List (2013) The Plant List. Version 1.1. Disponível em <http://www.theplantlist.org/>. Acesso em 16 janeiro 2018.

Thiers B [continuamente atualizado] Index Herbariorum: a global directory of public herbaria and associated staff. New York Botanical Garden's Virtual Herbarium. Disponível em $<$ http:// sweetgum.nybg.org/science/ih/>. Acesso em 15 janeiro 2018.

Vidal WN \& Vidal MRR (2006) Botânica-organografia. $4^{\mathrm{a}}$ ed., $8^{\mathrm{a}}$ impressão. UFV, Viçosa. 67p.

Wood JRI, Mamani MF, Pozo P, Soto JD \& Villarroel Segarra D (2011) Guía Darwin P1. Chiquitania. Museo de Historia Natural Noel Kempff Mercado, Santa Cruz. Pp. 1-212.

\section{Lista de exsicatas}

Almeida S 443 (1.2). Alston 168 (1.1). Alves M 139 (5.1). Amaral IL 676 (3.1). Araujo D 419 (1.2). Assunção P 254 (4.5). Austin DF 7429 (1.1). Barretto KD (RB 662449) (2.1). Barroso GM (RB 662533) (2.1). Bastos MNC 590 (1.2), 1089 (1.2), 1243 (1.2), 1356 (1.2). Bertoldo J 3390 (4.3). Harley RM 1012 (4.1) Black GA 50 (1.1). BMTW 6715 (4.3). Brandão DB 01 (5.1). Campos MM 43 (5.1). Carauta JPP 7187 (2.1) Castellanos (R 155557) (2.1). CCV 8 (4.1). Chagas (MG 23059) (1.1). Cocucci AE (RB 552393) (2.1). Coelho J (MG 50404) (1.1). Correia CAS 38 (INPA) (4.4). Sobral M 15856 (4.4). Dubs B (ESA 1755) (4.1). Emygdio L 1896 (4.3). Fernandes A 48 (1.2). Forzza RC 6735 (4.2). Furtado PP 17241 (4.6). Gardner 6056 (1.2). Harley RM 21911 (4.4). Hatschbach GM 25040 (4.5), 56012 (4.1), (INPA 56012) (1.1), (INPA 195534) (4.2). Herter WG 1638 (2.1). Hoehne W (RB 325211) (1.1). Hyelen (INPA 214916) (1.1). Irwin HS (INPA 108128) (4.4). Jarenkow JA 3102 (3.1). Junk W 273 (1.1). Kegler A 790 (3.1). Kirkbride Jr JH (INPA 12318) (4.4). Lima CGB 39 (5.1). Lobatos LCB 202 (1.2). Loeuille B 719 (4.6), 737 (4.2), 773 (4.5), 790 (4.5), 842 (4.2). Luzenilda M (EAC 21269) (3.1). Mayer M (RB 657467) (2.1). Neto SVC 26 (1.2). Neto M 308 (4.5). Pires JM 6547 (1.1). Plowman T 9976 (4.4). Prance GT (INPA 42448) (4.5). Ribas OS 469 (2.1). Rito 4 (1.2). Rosa Jr WO 37 (1.2). Rosário CS 459 (4.3), 493 (4.3). Roth L (RB 93107) (1.1). Santos E 2555 (2.1). Santiago BC (MG 62224) (1.2). Silva FFS 602 (3.1). Silva GP 4532 (4.3). Silva NT 4928 (1.2). Simpson 56 (4.4). Smith LB 11018 (4.6). Souza CCV 8 (5.1). Teixeira LOA 16 (1.1). Thomas W (INPA 150989) (4.3). Tomasi EBR 01 (5.1). Tribess B 102 (3.1). Ule 5707 (1.1).

Editor de área: Dr. Gustavo Heiden Artigo recebido em 21/03/2018. Aceito para publicação em 27/09/2018. This is an open-access article distributed under the terms of the Creative Commons Attribution License. 